\title{
Reproductive Output and Morphometrics of Green Turtle, Chelonia mydas Nesting at the Kosgoda Rookery in Sri Lanka
}

\author{
E.M.L. Ekanayake ${ }^{1,2,3}$, T. Kapurusinghe ${ }^{3}$, M.M. $\operatorname{Saman}^{3}$, D.S. Rathnakumara ${ }^{3}$, \\ Samaraweera $^{4}$ and R.S. Rajakaruna ${ }^{1,2, *}$ \\ ${ }^{1}$ Department of Zoology, Faculty of Science, University of Peradeniya, Peradeniya, Sri Lanka \\ ${ }^{2}$ Postgraduate Institute of Science, University of Peradeniya, Peradeniya, Sri Lanka \\ ${ }^{3}$ Turtle Conservation Project (TCP), Panadura, Sri Lanka \\ ${ }^{4}$ Department of Molecular Biology and Biotechnology, Faculty of Science, University of Peradeniya, \\ Peradeniya, Sri Lanka
}

\section{Received: 26/07/2016; Accepted: 19/10/2016}

\begin{abstract}
Reproductive output provides data fundamental to the conservation and management of sea turtles. Five years of data on the reproductive output of female green turtles was collected from Kosgoda beach, the second largest sea turtle rookery in Sri Lanka. Egg size, clutch size, clutch frequency, female size, hatchling size, hatching success, nest depth, and incubation duration were recorded. A total of 1,492 nests comprising 166,358 eggs were laid by 575 nesting females during the study period. Larger females had a higher reproductive output, laying larger eggs, bigger clutches, and producing a greater number of eggs in total for a season. There was no relationship between clutch size and egg size, and the hatchling size did not depend on the egg size or the female size. The mean hatching success was $77.3 \%$ and the mean incubation duration was 50.6 days. Clutch size, egg size, female body size, and nest depth had no effect on hatching success of the green turtles nests laid at Kosgoda rookery. Even though the size of the nesting turtles and clutch size were similar to other green turtle populations, the reproductive output and clutch frequency of green turtle females nesting at Kosgoda rookery were low compared to the population at Rekawa beach in southern Sri Lanka and other green turtle populations worldwide. The shorter stretch of beach $(1 \mathrm{~km})$ used to collect data may be a reason for this difference, precluding observation of re-nesting efforts by the female turtles.
\end{abstract}

Keywords: Green turtle, Chelonia mydas, Kosgoda rookery, Reproductive output, Morphometrics.

\section{INTRODUCTION}

Reproductive output is an important aspect of life history and fundamental to understanding the species reproductive biology which informs development of effective conservation and management plans for individual populations. The reproductive output can vary among individuals due to differences in adult female body size (Olsson and Shine, 1996). Sea turtles show indeterminate growth as adults, although many turtle species do not continue to grow significantly after sexual maturity (Carr and Goodman, 1970; Avery, 1994). However, the body size of nesting female turtles can vary among different populations and it is not a dependable indicator of sexual maturity (Limpus et al., 1994). For example, the east Australian population of green turtles are first observed nesting with a curved carapace length (CCL) of 90 - $100 \mathrm{~cm}$ (Limpus and Chaloupka, 1997) compared with approximately $80 \mathrm{~cm}$ in the Hawaiian Archipelago (Balazs and Chaloupka, 2004; Zug et al., 2002) and Gulf of Mannar (Agastheesapillai and Thiagarajan, 1979). The estimated age at sexual maturity of the green turtles also varies among different populations, ranging from 12 - 26 years in Costa Rica, 24 - 36 years in Suriname (Frazer and Ladner, 1986), 27 - 33 years in the Virgin Islands, USA, and 40 50 years in the Hawaiian Archipelago (Zug and Balazs, 1985), and 42 - 44 years in Atlantic green turtles (Goshe et al., 2010). Type of diet (Wood and Wood, 1980; Balazs, 1982; Bjorndal, 1985), availability of food (Balazs, 1979) and climatic conditions (Balazs, 1982) are important factors in determining growth of sea turtles. For example, captive green turtles reach maturity much earlier (8 - 11 years; Wood and Wood, 1980) than wild turtles as the former are usually fed with a high protein diet and hence grow more rapidly than individuals in the wild with herbivorous diets (Wood and Wood, 1980). Moreover, those living in colder habitats have a slower growth rate (Balazs, 1982). 
The number of eggs laid by a female varies among conspecifics of different sizes (Olsson and Shine, 1996). Several studies reported a positive relationship between the female body size and the clutch size of green turtles (Hirth, 1980; Bjorndal and Carr, 1989; Hirth, 1997; Broderick et al., 2003). Moreover, the clutch size significantly increases with the age of the female (Bjorndal and Carr, 1989). Size at maturity of the female affects the lifetime reproductive output of an individual female turtle (Tiwari and Bjorndal, 2000). Females that mature early in their life have a higher reproductive output per season than late maturing individuals (Iverson, 1992). This indicates that the body size of a female may set the upper limit to reproductive output, but Shine (1992) points out that this limit may not be reached if conditions are suboptimal. Resource availability at the foraging ground and inter-annual climate variability directly affect the body size and thereby reproductive output of the green turtles per season (Limpus and Nicholas, 1988; Bjorndal, 1997; Broderick et al., 2001).

Sea turtles produce multiple clutches of eggs per nesting season, greatly reducing the likelihood of all eggs being lost because the clutches are temporally and spatially separated (Miller, 1997). The mean number of eggs in a clutch varies among the individuals of the same species (van Buskirk and Crowder, 1994). The number of clutches laid by a female varies considerably from year to year and is dependent on dietary, behavioural and physiological factors (van Buskirk and Crowder, 1994). In green turtles, the number of clutches is independent of female body size (Broderick et al., 2003).

Miller (1997) studied green turtle morphometrics and reported that the average size of green turtle eggs is $4.5 \mathrm{~cm}$ diameter and weight is $46 \mathrm{~g}$, and there is little variation in the size of the eggs within a species and even less variation within a clutch. Egg size of green turtles is significantly correlated with female body size where larger females produce larger eggs (Bjorndal and Carr, 1989).

Green turtles do not nest annually (Miller, 1997). A recent study by Ekanayake et al. (2010a) described the nesting behavior of green turtles at the Kosgoda rookery, the second largest turtle rookery in Sri Lanka. Female green turtles nesting at the Kosgoda rookery lay one to ten clutches of 24 to 200 eggs every 1.5 to 4 years (Ekanayake et al., 2010a). These clutches are laid during a nesting season with an inter-nesting period of seven to 43 days between successive clutches. Even though nesting takes place year round, $66 \%$ of nesting at the Kosgoda rookery occurs between February and June, with highest and the lowest number of nests recorded in April and November, respectively (Ekanayake et al., 2010b). The present study was carried out to determine the morphometrics and the reproductive output of female green turtles nesting at Kosgoda rookery to better understand the importance of the rookery in context of green turtle populations in the northern Indian Ocean and worldwide.

\section{MATERIALS AND METHODS}

\section{Study site}

The $4 \mathrm{~km}$ stretch of beach at the Kosgoda rookery $\left(6^{\circ} 33^{\prime} \mathrm{N}, 80^{\circ} 02^{\prime} \mathrm{E}\right)$ in the south-western coast of the island has year-round nesting of five species of sea turtles: green turtle (Chelonia mydas), leatherback turtle (Dermochelys coriacea), loggerhead turtle (Caretta caretta), hawksbill turtle (Eretmochelys imbricata) and olive ridley turtle (Lepidochelys olivacea; Deraniyagala, 1953). Close to the Colombo Galle main road, in an area where the human population is $\sim 7,500$, the coastline is influenced by a range of anthropogenic factors but beach access within the rookery operated area is limited and, thereby, provides a virtually undisturbed nesting area for sea turtles. The slope of the beach is less than $30^{\circ}$ and the tidal amplitude is very low. Most of the beach area comprises fine sand. A $1 \mathrm{~km}$ stretch of beach at Kosgoda rookery was selected (Figure 1) for the study as there is large number of nesting occurs throughout the year and the nesting was monitored for $24 \mathrm{~h}$ throughout the five year study period from 2003 to 2008 . 


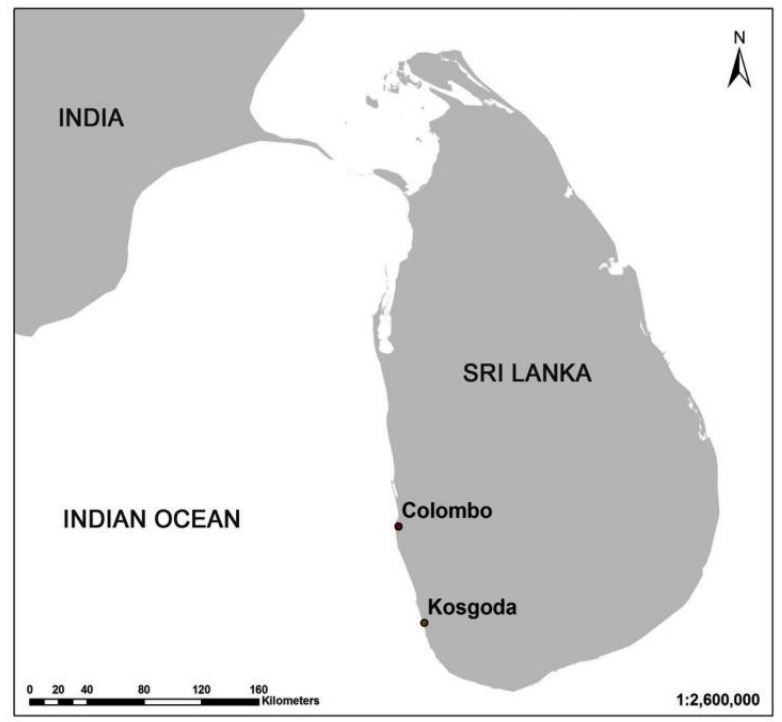

Figure 1: Kosgoda nesting beach on the southwest coast of Sri Lanka

\section{Data collection}

\section{Eggs, hatchlings and nesting females}

All the eggs laid by a female green turtle were visually counted at the time of oviposition or by excavating the nest after the hatchlings emerged to determine the clutch size. If a female selected an unsuitable place for nesting, the nest was relocated to a safer place on the same beach. Weight and diameter were measured for ten eggs selected randomly while the female was laying. Eggs were cleaned using a soft dry cloth to remove adhering sand and weighed to the nearest $0.1 \mathrm{~g}$ using a spring balance. Egg diameter was measured using a plastic vernier caliper, holding the egg by fingers and by pressing a finger gently against the shell to form a dimple as explained in Miller (1999). The maximum and minimum diameter was measured to the nearest $0.1 \mathrm{~mm}$ and the average was taken. The eggs removed for measurements were carefully placed back in the nest before the female covered the nest. After the female turtle had left the beach, a steel cable mesh 'nest screen' (measuring $1 \mathrm{~m}^{2}$ ) with a mesh size of $5 \mathrm{~cm} \times 5 \mathrm{~cm}$, was placed over the nest. This screen prevented predators from excavating the nest, yet was large enough to allow the emergence of hatchlings. The beach was patrolled for $24 \mathrm{~h}$ a day and the nests were guarded until all of the hatchlings emerged.

The curved carapace length (CCL) and curved carapace width (CCW) of nesting females were measured to the nearest $0.1 \mathrm{~cm}$ using a 1.5 $\mathrm{m}$ flexible measuring tape.The size of emerging hatchlings was measured for in situ nests but not for those that were relocated. Ten randomly chosen hatchlings were weighed to the nearest $0.1 \mathrm{~g}$ using a spring balance and the straight carapace length (SCL) and the straight carapace width $(\mathrm{SCW})$ were measured to the nearest 0.1 $\mathrm{mm}$ using plastic vernier calipers.

\section{Incubation duration, hatching success and nest depth}

The incubation duration was determined by counting the number of days from oviposition to the date when the first hatchling emerged from the nest. The nest was excavated five days after the first hatchling emergence. Any live hatchlings remained in the nest were counted and released to the sea. Dead hatchlings, eggshells and unhatched eggs were removed from the nest and counted to calculate the hatching and emergence success according to Miller (1999) as follows:

$$
\begin{aligned}
& \text { Hatching Success }=\frac{\text { No.of egg shells }}{\text { No.of egg shells }+ \text { unhatched eggs }} \\
& \text { Emergence Success }=\text { Hatching success- Live \& dead } \\
& \text { hatchling \% in the nest }
\end{aligned}
$$

The unhatched eggs were opened to determine the development stage of the embryo. Embryos were categorised as 'early' (embryos less than $1 \mathrm{~cm}$ diameter), 'mid' (embryos $1 \mathrm{~cm}$ to $3 \mathrm{~cm}$, with big yolk sack) and 'late' development (completely developed embryo). Undeveloped eggs without an embryo or egg yolk were also counted. Rotten eggs were recorded as 'unknown' because their developmental stages could not be identified. The percentage of hatched and unhatched eggs and dead hatchlings inside the nest were calculated as proportions of the total number of eggs. The nest depth was measured as the distance from the surface of the nest to the bottom of the nest when the nest was excavated and the contents were removed. Data on incubation and hatchling morphometrics were collected only for the first three years of the study period from 2003-2006. Data from the relocated nests were not considered to determine the reproductive output of females.

\section{Data analysis}

The total number of the eggs in all of the clutches laid by an individual turtle within a single nesting season was denoted as 
reproductive output per season. The correlation between adult female body size (measured as CCL) and reproductive output per season, egg count per nest (clutch size), clutch frequency (number of clutches per season), egg size (egg diameter and egg weight), and hatchling size were analysed individually using a linear regression. All the data sets were checked for the normality and the outliers were removed before analysis. Significance of the associations between female body size and clutch size, number of clutches, egg size, hatchling body size (SCL) and total number of eggs laid during the season were also determined using a linear regression. The associations between clutch size, egg size, number of clutches, hatchling size, and total number of eggs were again analysed using a linear regression. Effect of nest depth on the hatching success was analysed using a polynomial regression. Data analyses was carried out using Minitab version 14.

\section{RESULTS}

\section{Eggs}

A total of 166,358 eggs in 1,492 nests were recorded along the $1 \mathrm{~km}$ study site at the Kosgoda rookery for the five year study period (Table 1). The mean number of eggs per nest (clutch size) was $113.7 \pm 1.58$ (Table 1) with a range of 24 to 209 eggs per clutch (Table 2). The minimum number of eggs (24) was recorded from a female which was disturbed while laying eggs and never returned to nest at the same stretch of beach during that nesting season. The highest number of eggs laid by an individual female in a single season was 1,249 eggs, which were laid in nine nests during a five month period from October 2005 to February 2006. The mean number of eggs laid by a green turtle per season was $289.3 \pm 185.5$ (Table 1). The mean weight and diameter of eggs laid by green turtles at Kosgoda rookery were $46.5 \pm 6.3 \mathrm{~g}$ and $41.8 \pm 2.1 \mathrm{~mm}$, respectively (Table 2). The mean number of clutches deposited by a nesting female during a nesting season was $2.17 \pm 1.58$ (Table 1 ).

\section{Females}

A total of 575 females nested during the study period, with 157 as the highest nesting population during 2005 and 2006 and 87 turtles as the lowest nesting population in the subsequent nesting season (Table 1). Morphometric measurements were taken from418 females (Table 3). The mean CCL for the green turtle population nesting at the Kosgoda rookery was $105.0 \pm 5.9 \mathrm{~cm}$ and mean CCW was $94.7 \pm 6.2 \mathrm{~cm}$ (Table 3).

Table 1: Reproductive output measured as the number of eggs, number of clutches, number of eggs per female and the clutch frequency for green turtles nesting at Kosgoda rookery.

\begin{tabular}{ccccccr}
\hline Year & $\begin{array}{c}\text { Total } \\
\text { no. of } \\
\text { females }\end{array}$ & $\begin{array}{c}\text { Total no. } \\
\text { of eggs }\end{array}$ & $\begin{array}{c}\text { Total no. } \\
\text { of clutches }\end{array}$ & $\begin{array}{c}\text { Mean no. of } \\
\text { eggs per } \\
\text { female }\end{array}$ & $\begin{array}{c}\text { Mean no. clutches } \\
\pm \text { SD/season }\end{array}$ & Range \\
\hline $2003-2004$ & 108 & 32,558 & 292 & 301.5 & $2.28 \pm 1.75$ & $1-10$ \\
$2004-2005$ & 113 & 32,112 & 288 & 284.2 & $2.01 \pm 1.35$ & $1-7$ \\
$2005-2006$ & 157 & 44,600 & 400 & 284.1 & $2.33 \pm 1.74$ & $1-8$ \\
$2006-2007$ & 87 & 23,303 & 209 & 267.9 & $1.90 \pm 1.26$ & $1-7$ \\
$2007-2008$ & 110 & 33,785 & 303 & 307.1 & $2.19 \pm 1.59$ & $1-9$ \\
\hline Total & $\mathbf{5 7 5}$ & $\mathbf{1 6 6 , 3 5 8}$ & $\mathbf{1 , 4 9 2}$ & $\mathbf{2 8 9 . 3} \pm \mathbf{1 8 5 . 5}$ & $\mathbf{2 . 1 7} \pm \mathbf{1 . 5 8}$ & $\mathbf{1 - 1 0}$ \\
\hline
\end{tabular}


Table 2: Mean clutch size, egg weight and egg diameter for green turtles nesting at Kosgoda rookery.

\begin{tabular}{cccc}
\hline Year & $\begin{array}{c}\text { Mean clutch size } \mathbf{\pm S D} \\
(\mathbf{r a n g e} ; \mathbf{n})\end{array}$ & $\begin{array}{c}\text { Mean weight } \mathbf{\pm} \text { SD/g } \\
(\mathbf{r a n g e} ; \mathbf{n})\end{array}$ & $\begin{array}{c}\text { Mean diameter } \pm \\
\text { SD/mm }(\mathbf{r a n g e} \mathbf{n})\end{array}$ \\
\hline $2003-2004$ & $13.8 \pm 31.2$ & $41.8 \pm 4.3$ & $42.1 \pm 2.5$ \\
& $(27-200 ; 209)$ & $(28.5-50.4 ; 271)$ & $(10.7-50.7 ; 271)$ \\
\hline $2004-2005$ & $108.4 \pm 29.6$ & $46.1 \pm 5.0$ & $42.0 \pm 1.9$ \\
& $(31-170 ; 200)$ & $(30.0-60.9 ; 248)$ & $(35.3-51.5 ; 248)$ \\
\hline $2005-2006$ & $118.1 \pm 29.0$ & $45.5 \pm 6.3$ & $41.9 \pm 1.9$ \\
& $(29-209 ; 267)$ & $(33.3-64.2 ; 366)$ & $(31.9-48.9 ; 366)$ \\
\hline $2006-2007$ & $112.0 \pm 32.3$ & $46.5 \pm 4.0$ & $41.9 \pm 1.2$ \\
& $(24-164 ; 129)$ & $(36.4-59.6 ; 164)$ & $(38.7-47.7 ; 164)$ \\
\hline $2007-2008$ & $111.8 \pm 29.9$ & $52.2 \pm 5.8$ & $41.0 \pm 2.1$ \\
& $(28-195 ; 277)$ & $(30.1-71.0 ; 291)$ & $(30.7-47.3 ; 291)$ \\
\hline Total & $\mathbf{1 1 3 . 7} \pm \mathbf{2 7 . 3}$ & $\mathbf{4 6 . 5} \pm \mathbf{6 . 3}$ & $\mathbf{4 1 . 8} \pm \mathbf{2 . 1}$ \\
\hline
\end{tabular}

$\mathrm{SD}=$ Standard Deviation; $\mathrm{n}=$ number of clutches or eggs

Table 3: Size (measured as CCL and CCW) of the green turtle nesting at Kosgoda rookery.

\begin{tabular}{lccc}
\hline \multicolumn{1}{c}{ Year } & $\begin{array}{c}\text { No. of females } \\
\text { measured }\end{array}$ & $\begin{array}{c}\text { Mean CCL } \pm \text { SD/cm } \\
\text { (range) }\end{array}$ & $\begin{array}{c}\text { Mean CCW } \pm \text { SD } \\
(\text { range } / \mathbf{c m}\end{array}$ \\
\hline $2003-2004$ & 74 & $104.9 \pm 6.6(94.0-120.2)$ & $95.0 \pm 7.2(83.6-114.0)$ \\
$2004-2005$ & 100 & $104.3 \pm 5.8(87.5-117.7)$ & $94.6 \pm 5.6(80.2-107.5)$ \\
$2005-2006$ & 112 & $105.6 \pm 5.9(91.5-118.7)$ & $95.1 \pm 5.4(83.5-108.0)$ \\
$2006-2007$ & 48 & $106.2 \pm 6.0(94.3-117.2)$ & $95.0 \pm 7.2(79.2-109.7)$ \\
$2007-2008$ & 84 & $103.8 \pm 5.2(85.9-115.0)$ & $94.0 \pm 5.4(77.3-109.3)$ \\
\hline Total & $\mathbf{4 1 8}$ & $\mathbf{1 0 5 . 0} \pm \mathbf{5 . 9}(\mathbf{8 5 . 9 - 1 2 0 . 2})$ & $\mathbf{9 4 . 7} \pm \mathbf{6 . 2}(\mathbf{7 7 . 3 - 1 1 4 . 0})$ \\
\hline
\end{tabular}

$\mathrm{CCL}=$ Curved Carapace Length, $\mathrm{CCW}=$ Curved Carapace Width, $\mathrm{SD}=$ Standard Deviation

\section{Female size and reproductive output}

Larger females had a higher reproductive output, laying larger clutches and larger eggs and producing higher number of eggs in total during a nesting season. A highly significant correlation was observed between female size (CCL) and mean clutch size (Linear regression; $\mathrm{R}^{2}=0.108$, $p<0.001$, Figure 2a), the total number of eggs per season (Linear regression; $\mathrm{R}^{2}=0.010, p=$ 0.038 , Figure $2 b$ ), mean egg diameter (Linear regression; $\mathrm{R}^{2}=0.030, p<0.001$, Figure $2 \mathrm{c}$ ), and mean egg weight (Linear regression; $\mathrm{R}^{2}=0.044$, $p<0.001$, Figure 2d). However, there was no relationship between female size and the number of clutches per season (clutch frequency; Linear regression; $\mathrm{R}^{2}=0.001, p=0.438$, Figure 2e). The size of the adult female was not association with hatchling size (Linear regression; $\mathrm{R}^{2}=$ 0.094, $p=0.188$, Figure 2f).

\section{Incubation duration and hatchlings}

The mean incubation duration for green turtle nests at the Kosgoda was $50.6 \pm 3.6$ days (range 43-68 days; Table 4). Mean hatchling weight was $24.6 \pm 3.5 \mathrm{~g}$ (range 18.9 - 39.6); mean hatchling SCL and SCW were $46.5 \pm 2.8 \mathrm{~mm}$ (range $36.8-51.4$ ) and $36.6 \pm 2.9 \mathrm{~mm}$ (range 32.3 - 46.8), respectively (Table 4). Although larger females laid larger eggs, the female CCL was not associated with hatchling length (Linear regression; $R^{2}=0.094, p=0.188$, Figure 2f). Moreover, there was no significant relationship between the clutch size and egg diameter (Linear regression; $\mathrm{R}^{2}=0.008, p=0.055$, Figure $3 \mathrm{a}$ ). Similarly, hatchling size was not associated with egg size (Linear regression; $\mathrm{R}^{2}=0.004, p=$ 0.388 , Figure $3 b$ ). 

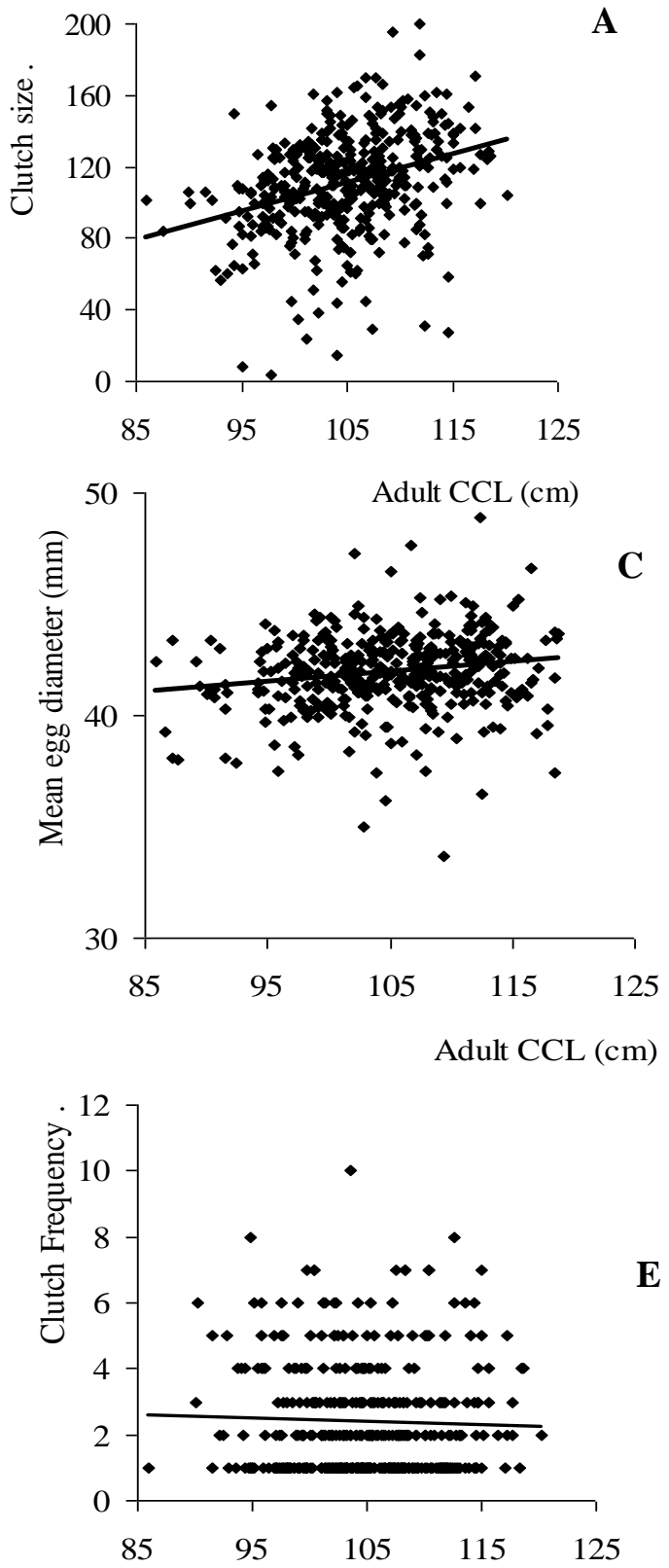

Adult CCL (cm)
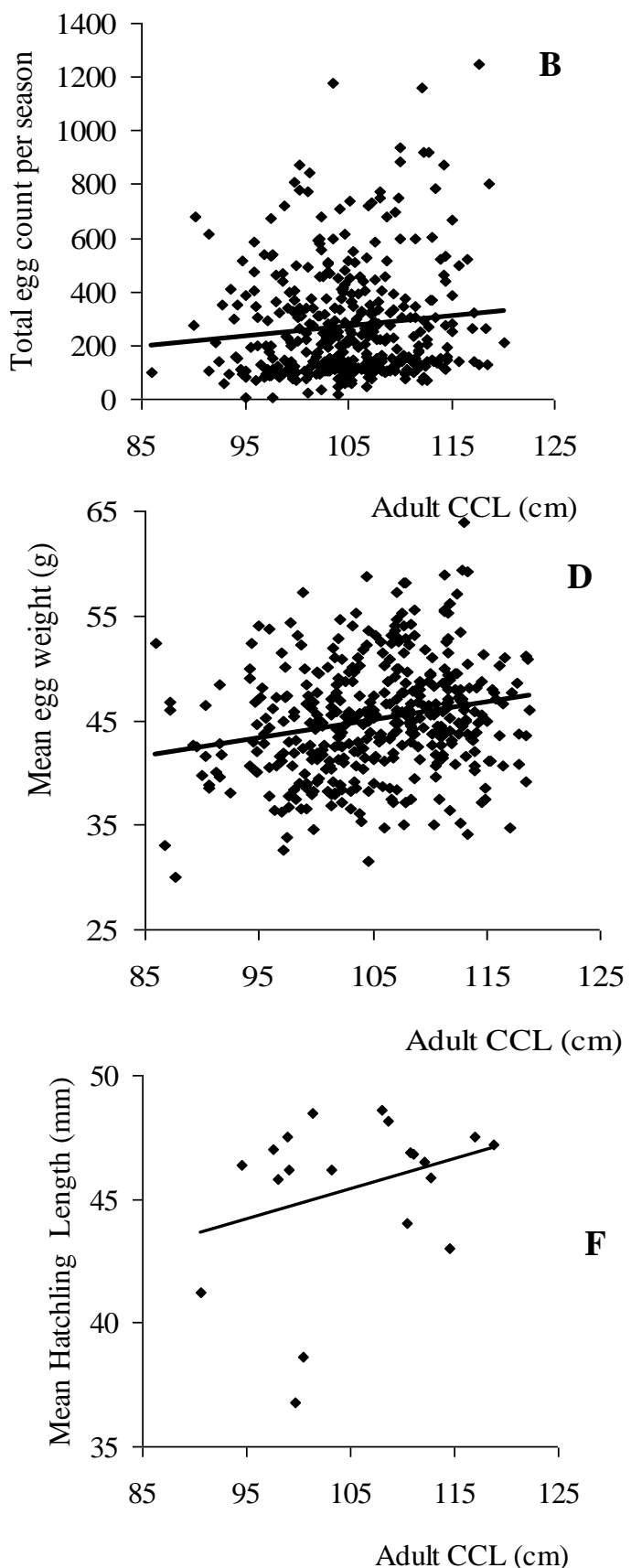

Figure 2: Relationship of female body size (measured as curved carapace length, CCL) with reproductive output parameters and morphometrics: clutch size, total number of eggs laid per season, egg diameter, egg weight and clutch frequency and hatchling size for the green turtle population nesting at Kosgoda rookery.

Hatching success, emergence success and nest depth

The mean hatching success of 526 clutches of green turtles nests at the Kosgoda turtle rookery was $77.3 \%$ ( $\mathrm{SD} \pm 22.2$ ), with $22.7 \%$ of eggs being non-viable, including the eggs that died at early, mid or late stage of development or undeveloped eggs or dead eggs that were difficult to categorize because they were rotten (Table 5; Figure 4). Of these non-viable eggs, most of them $(10.0 \%)$ were at an unknown stage of development and/or rotten eggs, and some were undeveloped eggs (7.3\%) with no sign of embryonic development (Figure 4). A small percentage of live hatchlings (1.8\%) was trapped in the nests and dead hatchlings $(1.2 \%)$ were also found inside the nest. The emergence success of hatchlings from green turtle nests at Kosgoda rookery was $74.3 \%$. The hatching success and emergence success for each year are given in the Table 4 . The mean nest depth of 482 green turtle nests was $72.9 \mathrm{~cm}(\mathrm{SD} \pm 11.88$, range $30 \mathrm{~cm}-114$ $\mathrm{cm}$; Table 4). 

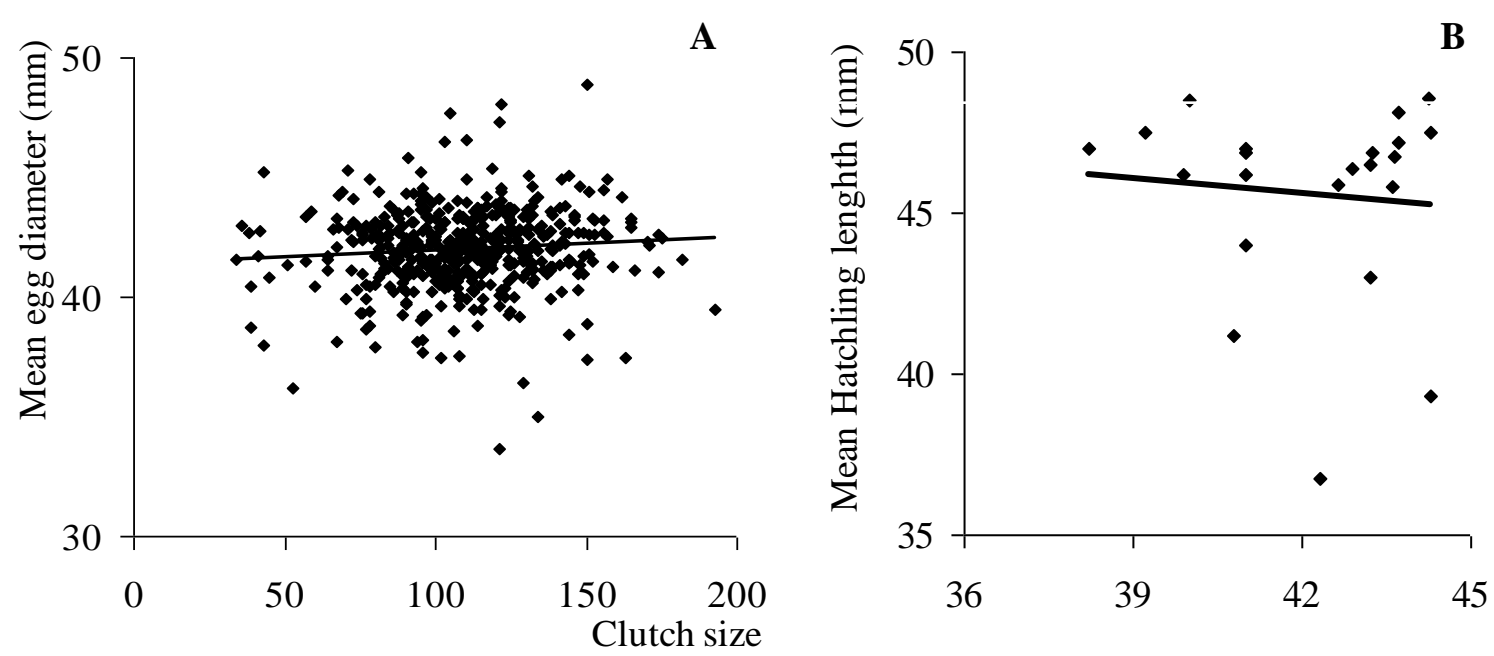

Mean egg diameter ( $\mathrm{mm})$

Figure 3: Relationship of clutch size with egg size and egg size with hatchling size for the green turtle population nesting at Kosgoda rookery.

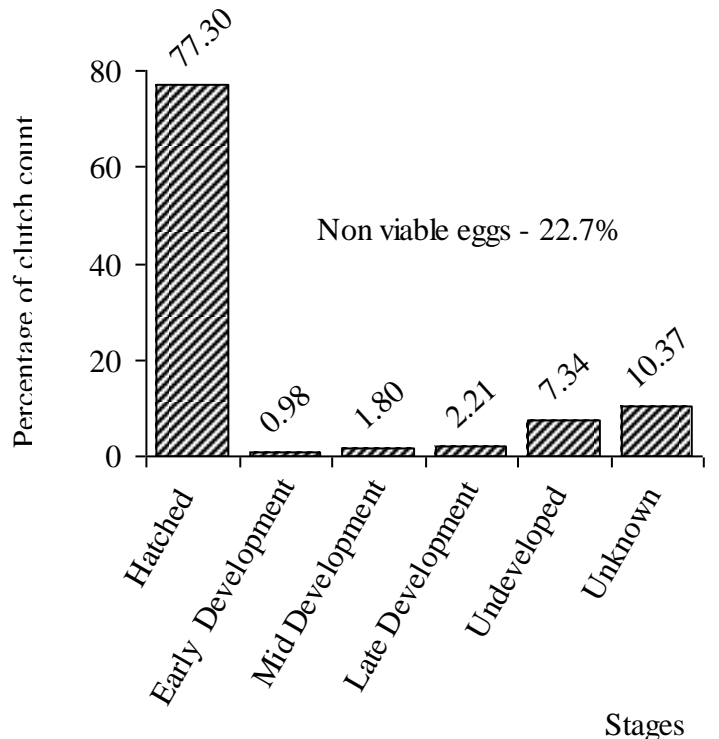

Figure 4: Estimates of hatching success and un-hatched, non-viable eggs in green turtle nests at Kosgoda rookery.

Table 4: Hatchling size, hatching success, emergence success and nest depth for the green turtles nesting at Kosgoda rookery.

\begin{tabular}{rcccc}
\hline Year & $\begin{array}{c}\text { Mean hatchling } \\
\text { size } \pm \text { SD/mm }\end{array}$ & $\begin{array}{c}\text { Hatching } \\
\text { success } \\
(\boldsymbol{\%})\end{array}$ & $\begin{array}{c}\text { Emergence } \\
\text { success }(\boldsymbol{\%})\end{array}$ & $\begin{array}{c}\text { Mean nest depth } \\
\pm \text { SD /cm }\end{array}$ \\
\hline $2003-2004$ & $46.6 \pm 2.4$ & 66.4 & 60.3 & $74.05 \pm 11.7(30-107)$ \\
$2004-2005$ & Data NA & 77.6 & 74.9 & $70.09 \pm 10.3(39-95)$ \\
$2005-2006$ & $45.8 \pm 4.1$ & 80.5 & 78.3 & $76.14 \pm 12.3(38-114)$ \\
$2006-2007$ & Data NA & 79.0 & 77.8 & $68.56 \pm 7.9(42-82)$ \\
\hline Total & $\mathbf{4 6 . 5} \pm \mathbf{2 . 8}$ & $\mathbf{7 7 . 3}$ & $\mathbf{7 4 . 3}$ & $\mathbf{7 2 . 9} \pm \mathbf{1 1 . 8 8}(\mathbf{3 0 - 1 1 4})$ \\
\hline
\end{tabular}


$\mathrm{NA}=$ Not available, $\mathrm{SD}=$ Standard Deviation

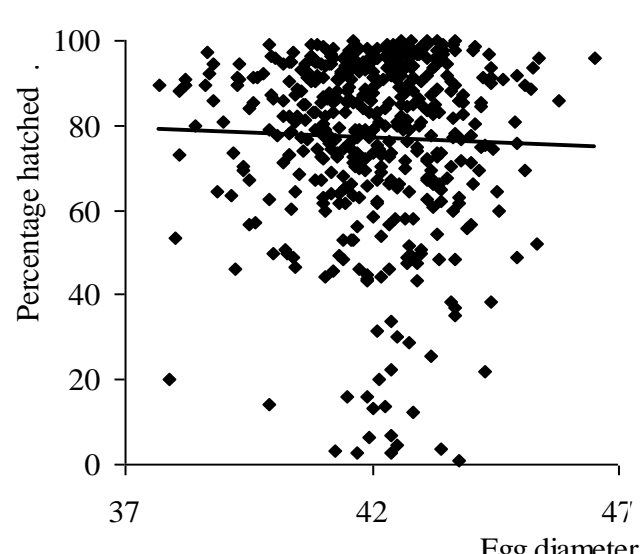

A

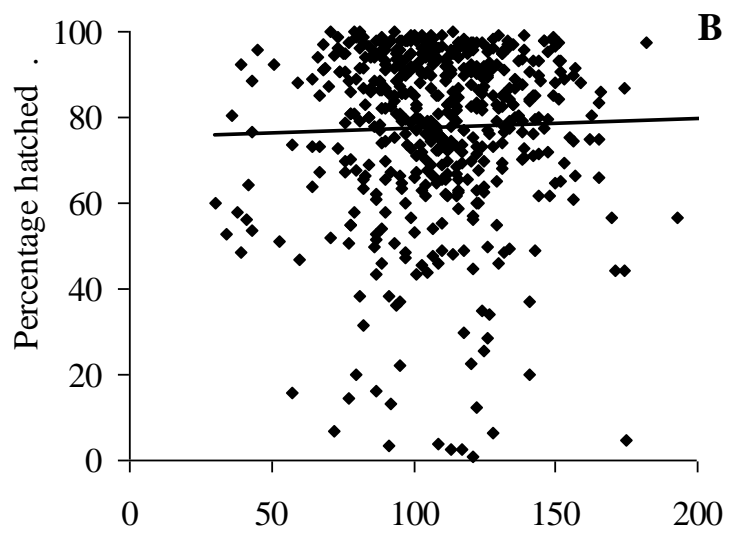

Egg diameter
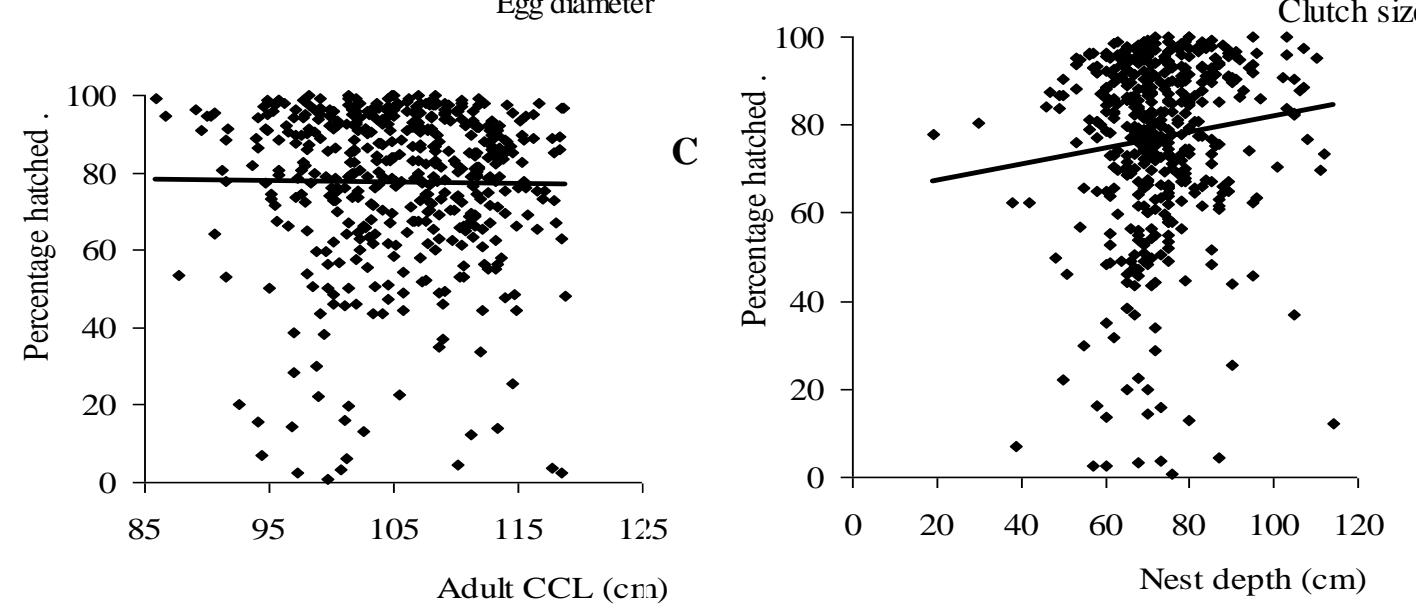

$\mathbf{D}$

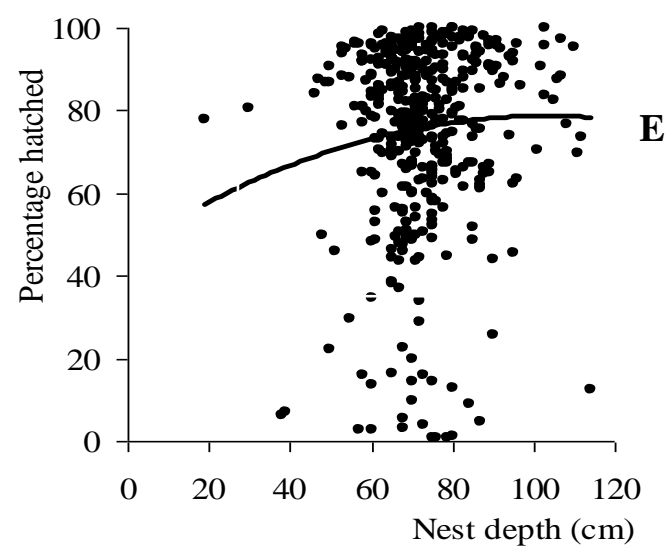

Figure 5: Relationship of hatching success with reproductive output parameters and morphometrics: egg size, clutch size, female size (measured as curved carapace length, CCL) and nest depth for the green turtle population nesting at Kosgoda rookery. 


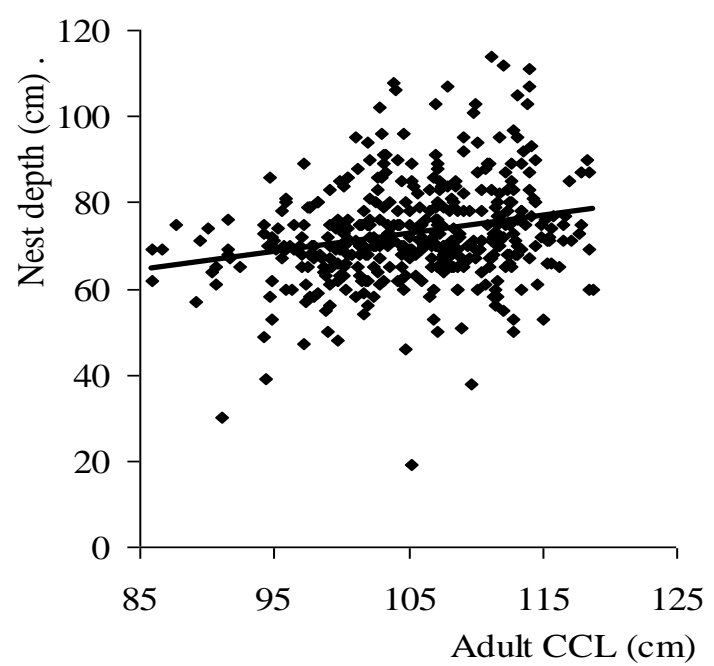

Figure 6: Relationship between female size and nest depth for the green turtle population nesting at Kosgoda rookery.

Egg size, clutch size, and female body size were not related to hatching success of green turtle nests at Kosgoda rookery (Linear regression; egg diameter $\mathrm{R}^{2}=0.003, p=0.185$, clutch size $\mathrm{R}^{2}=0.028, p=0.115$, adult $\mathrm{CCL} \mathrm{R}^{2}$ $=0.085, p=0.355$; Figure 5a, 5b and 5c). Moreover, the nest depth had no relationship with hatching success of eggs (Linear regression; $\mathrm{R}^{2}=0.008, p=0.055$ Figure $5 \mathrm{~d}$ ) however, polynomial regression predicted a negative relationship between nest depth over $100 \mathrm{~cm}$ and the hatching success (Figure 5e). Although larger females dug deeper nests, there was no statistically significant relationship found between size of the female and the depth of the nest (Linear regression; $\mathrm{R}^{2}=0.010, p=0.10$; Figure 6).

\section{DISCUSSION}

The female green turtles nesting at the Kosgoda rookery produced an average of $289.3 \pm 185.5$ eggs per nesting season, which is much lower than the reproductive output of the same species nesting at other locations. In Rekawa, the largest green turtle rookery in Sri Lanka, the females have a higher reproductive output of 480 eggs per season (as calculated from 752 females; Ekanayake, 2003). Bjorndal (1980) recorded in 14 cohorts of green turtles nesting at Tortuguero, Costa Rica, laying a mean of 397.2 eggs per season. Limpus et al. (1984) recorded $115.2 \pm$ 27.88 eggs per clutch from 50 individuals who laid $5.06 \pm 1.99$ clutches per season per female on Heron Island within the Great Barrier Reef in Australia. Ali et al. (2005) observed that 49 green turtles at Mak Kepit beach on Redang Island, Malaysia, laid a mean of 435 eggs during one nesting season. Broderick et al. (2003) showed that the major factor contributing to the reproductive output is female body size whereby larger females lay a higher number of eggs. However, Iverson (1992) examined the correlates of reproductive output per season and presented data from 51 populations of turtles representing 35 species and eight families, reporting that annual reproductive output may be related to the rate at which a turtle acquires its resources, with slow rates resulting in slow growth, delayed maturity, and reduced energy available for annual reproductive output. Iverson (1992) analysed the factors that affect the reproductive output by removing the effect of body mass on reproductive output and reported that individual clutch mass was positively correlated strongly with latitude and somewhat with diet where it is higher in carnivores. Moreover, the total annual clutch mass was correlated most strongly with a decrease in average age at maturity. Species of turtles in high latitudes have shorter nesting seasons, and therefore lower clutch frequencies, and higher size-adjusted individual clutch mass (Iverson, 1992).

Female green turtles nesting at Kosgoda rookery had a mean clutch size of 111.5 eggs, which was similar to that of Rekawa turtle rookery (112.1; Ekanayake, 2003) and also many other green turtle populations around the world (112.2 at Tortuguero, Costa Rica- Bjorndal and Carr, 1989; 112.8 for 24 populations of green turtles worldwide, Miller, 1997). Although the mean clutch size of females nesting at Kosgoda is similar to that of the females at Rekawa, the clutch frequency is much lower at Kosgoda (2.17 clutches per season) than at Rekawa (4.0; Ekanayake, 2002) and this clearly accounts for the low reproductive output calculated in the 
current study for the Kosgoda population. Most re-nesting attempts occur within $200 \mathrm{~m}$ to $600 \mathrm{~m}$ from the previous attempt (Miller, 1997). Therefore, there is a strong possibility that nesting attempts during a single nesting season were missed on the $1 \mathrm{~km}$ study site at Kosgoda, and hence the observed clutch frequency could be lower than the actual. The length of the stretch of beach used to collect data has to be considered when determining the clutch frequency and the reproductive output of a female (SWOT, 2011). For example, the data for Rekawa was collected from a $2 \mathrm{~km}$ stretch of beach (Ekanayake, 2002) and in Tortuguero an 8 $\mathrm{km}$ stretch was used to collect data (Bjorndal, 1980) whereas in the present study only $1 \mathrm{~km}$ was surveyed. Therefore, differences in clutch frequency and reproductive output reported in the current study could be attributed to turtles at Kosgoda laying undetected nests outside of the study site and not being included in our calculations.

Larger females of the nesting population of green turtles at Kosgoda laid larger clutches. The available space of the coelomic cavity of females affects their carrying capacity of a female (Broderick et al., 2003) and hence, larger females can carry more eggs to make up a clutch. The clutch size should also be an outcome of the interactions among the egg size (yolk energy required for embryonic development and post hatchling survival and dispersal), as well as the physical and ecological limitations of the female (Miller, 1997). While some studies have determined relationships between CCL or clutch size and egg size (e.g. Bjorndal and Carr, 1989; Hays et al., 1993) others have found no such relationship (e.g. Hays and Speakman, 1991; Broderick et al., 2003). Thus, Broderick et al. (2003) argue that the egg size cannot be ruled out as an important variable in the reproductive output of our population.

The mean egg weight and diameter for the green turtles at Kosgoda was $46.4 \mathrm{~g}$ and 41.8 $\mathrm{mm}$, respectively. The largest green turtle eggs of $53.2 \mathrm{~g}$ and $45.1 \mathrm{~mm}$ were reported from Peng$\mathrm{Hu}$ Archipelago, Taiwan (Chen and Cheng, 1995); the smallest eggs of $36 \mathrm{~g}$ and $40 \mathrm{~mm}$ were recorded at Sarawak Island (Hirth, 1980). Hence, the eggs of the green turtle population nesting at Kosgoda were of moderate size for the species. This could be because the females nesting at Kosgoda rookery were of medium size (mean CCL $105.0 \mathrm{~cm}$ ) compared to other nesting turtles in the world $(123.3 \mathrm{~cm}$ in Praia do Forte, Bahia, Brazil (Marcovaldi and Laurent, 1996); $118.6 \mathrm{~cm}$ in Fernando de Noronha Archipelago, Brazil (Bellini et al., 1996); $91.5 \mathrm{~cm}$ in Alagadi Beach, Northern Cyprus (Broderick et al., 2003); $82 \mathrm{~cm}$ in Mexico (Hirth, 1997)).A highly significant relationship was found between the female CCL and mean egg diameter and mean egg weight at Kosgoda. Bjorndal and Carr (1989) also determined egg size to be significantly correlated with carapace length and Congdon and Gibbons (1985) observed that egg size increased with the body size for the twelve species of freshwater and terrestrial turtles. However, Broderick et al. (2003) observed no relationship of the adult CCL with the egg size or weight, but used only 11 green turtle clutches for their analysis while the present study included 404 clutches. There was no relationship between clutch size and egg size of the Kosgoda green turtle population, which is consistent with previous studies of green turtles (Bjorndal and Carr, 1989; van Buskirk and Crowder, 1994).

The average number of clutches laid per female per season at Kodgoda rookery was 2.17 with a range of 1-7. Moll (1979) predicted that clutch frequency should increase with adult CCL in most species of turtles, suggesting that the clutch size, egg size, and number of clutches are adaptive compromises that facilitate the survival of the species. The number of clutches laid per season will be an evolutionary advantage for separating the total reproductive output per season into small groups in the context of risks such as predation, erosion, length of the nesting season, and the energy required for reproduction (Moll, 1979). However, there was no correlation between body size and clutches per season for females nesting at Kosgoda rookery. Other studies on green turtle populations that also observed that no significant relationship existed between body size and clutches per season include Florida, USA (Johnson and Ehrhart, 1996), Colola beach, Michoacán, México (Alvarado-Díaz et al., 2003) and Cyprus (Broderick et al., 2003).

The mean incubation duration calculated at the Kosgoda site was 50.6 days $(\mathrm{SD} \pm 3.6$, range 43-68), similar to that of 52.8 days ( $\mathrm{SD} \pm 3.8$, range 43-68) at the Rekawa turtle rookery (Ekanayake, 2002) and 49.3 days in Wan-an Island, Peng-Hu Archipelago, Taiwan (Chen and 
Cheng, 1995). However, the Kosgoda population had a shorter incubation duration compared to 64.5 days in Honolulu Hawaii (Balazs, 1980) and 57 days in Caribbean region (Hirth, 1997). Incubation period is dependent on nest temperature (Mrosovsky, 1982: Marcovaldi et al., 1997).The sex of sea turtles depends on the temperature during the thermo sensitive period of incubation and, hence, incubation duration can be used as an index of sex (Marcovaldi et al., 1997; Mrosovsky et al., 1999). The estimated sex ratio of males and females was 30:70 for Rekawa rookery (Ekanayake, 2002) and therefore, it can be predicted that the green turtles nesting at Kosgoda may also be producing female skewed hatchlings. Recently, Rajakaruna and Ekanayake (2014) and Hewapathiranage et al. (2015) showed that green turtle hatchlings emerging from eggs relocated and incubated in hatcheries along southwestern coast of Sri Lanka including Kosgoda were highly skewed towards females.

Hatchlings at Kosgoda have a mean SCL of $46.5 \mathrm{~mm}(\mathrm{SD} \pm 2.8)$ and mean body weight was $24.6 \mathrm{~g}(\mathrm{SD} \pm 3.5)$. This was within the range of many green turtle populations around the world: Honolulu, Hawaii (Balazs, 1980), 96 populations from worldwide (van Buskirk and Crowder, 1994) and Wan-an Island, Peng-Hu Archipelago, Taiwan (Chen and Cheng, 1995). Hirth (1980) stated that for all populations of sea turtles the mean carapace length of hatchlings is a few millimeters larger than the mean egg diameter. Hence, when the mean egg diameter increases, the hatchling size will increase.

The percentage hatching success of green turtles nesting at Kosgoda rookery was $77.3 \%$, similar to that recorded by Chen and Cheng (1995; 70\% in Peng-Hu Archipelago, Taiwan) and by Ozdemir and Turkozan (2006; 75.3\% in northern Cyprus). The hatching success of the green turtles nesting at Rekawa turtle rookery (82\%; Ekanayake, 2003) is slightly higher than that of Kosgoda. In general, hatching success varies from $2 \%$ to $88 \%$ among the green turtle populations in the world (Hirth, 1997). The hatching success of green turtle eggs did not depend on the clutch size, egg size or female body size at Kosgoda. However, Gutzke and Packard (1985) observed a significantly higher hatching success with increasing egg size for the painted turtles (Chrysemys picta). Many factors affect hatching success, substrate water content and salinity (Mortimer, 1990; Foley et al., 2006), geographical location (Tiwari and Bjorndal, 2000), sand particle size (Mortimer, 1990), and nest site location (Foley et al., 2006). High embryo mortality of hatchery relocated green turtle eggs due to handling of eggs has been reported (Hewavisenthi and Kotagama, 1991). The Kosgoda beach is an open beach with clean sand and low water content due to the slope of the beach. A detailed study on the biotic and abiotic factors affecting the hatching success has not been carried out in Sri Lanka.

Clutches with a nest depth between $60-100$ $\mathrm{cm}$ had a higher hatching success than shallower or deeper nests at Kosgoda. The average nest depth for green turtles is $70 \mathrm{~cm}$ (IUCN, 2005). The mean nest depth of females nesting at Kosgoda rookery was $72.9 \mathrm{~cm}$ with a range of 30 $-114 \mathrm{~cm}$. Similar average nest depths of $69 \mathrm{~cm}$ and $67.6 \mathrm{~cm}$ have been reported by Chen and Cheng (1995) in Wan-An Island, Taiwan and Ozdemir and Turkozan (2006) in Northern Cyprus, respectively. The depth of green turtle nests at Kosgoda rookery was not related to the size of the individual digging it. Hays et al. (1993) also found that there was no relationship between adult size and nest depth in green turtle populations nesting in Ascension Island. Dryness of the sand is a factor which is related to the nest depth, and turtles tend to dig deeper body pits, leading to greater nest depths, in dryer sand. Moreover, the beach may accumulate or lose sand during the incubation period and, hence, the nest depth could change between the time of oviposition and excavation. Therefore, nest depth should be measured just after oviposition, but most of the time this is not possible due to the likelihood of disturbing the nesting turtle.

Nest depth is an important factor influencing hatching success. Mortimer (1990) found that hatching success was positively but weakly correlated with nests depth in the green turtles nesting in Ascension Island. Similarly, a positive weak correlation between the nest depth and hatching success of the green turtles nesting at Kosgoda rookery was observed in the current study. In the same population, hatching success showed a negative correlation with the nest depth when it exceeded $100 \mathrm{~cm}$. Deeper nests prolong the hatchling emergence and have greater risk of higher number of dead hatchlings (Van De Merwe et al., 2005; Glen et al., 2005). 


\section{CONCLUSION}

Reproductive output and clutch frequency of green turtle females nesting at the Kosgoda rookery were low compared with other populations of green turtles as some variables may be underestimated due to short study beach length. Larger females had a higher reproductive output as they laid a higher number of eggs as well as larger eggs. However, larger eggs did not produce larger hatchlings as various environmental factors and incubation duration can affect the hatchling size. A comparatively high hatching success of $77.3 \%$ was recorded from green turtle nests at the Kosgoda rookery, with a mean incubation duration of 50.6 days. The clutch size, egg size, female body size and the nest depth had no effect on hatching success. Estimating reproductive output is important for long-term monitoring of life history traits of the green turtle to provide a meaningful insight into their conservation.

\section{ACKNOWLEDGEMENTS}

Authors thank the staff of the Turtle Conservation Project (TCP) for their technical support, Department of Wildlife Conservation for granting permission to carry out this study, National Science Foundation (NSF), Sri Lanka (SIDA/2005/BT/01), UNDP-GEF/SGP small grant programme, and International Foundation for Science (IFS), Sweden (A/3863-1) for financial support.

\section{REFERENCES}

Agastheesapillai, A. and Thiagarajan, R. (1979). Biology of the green turtle Chelonia mydas in the Gulf of Mannar and Palk Bay. Journal of the Marine Biology, India. 21:45-60.

Ali, A., Kassim, K., Yaacon, K., Razak, S.A. and Talib, Z. (2005). Individual nest site preference of green turtle, Chelonia mydas, on Mak Kepit beach and its relation with hatching emergence success. Proceedings of the $2^{\text {nd }}$ International symposium on SEASTAR 2000 and Asian Bio-logging Science (The 6th SEASTAR 2000 Workshop) (2005). 4549.

Alvarado-Díaz, J., Arias-Coyotl, E., and DelgadoTrejo, C. (2003). Clutch Frequency of the Michoacán Green Sea turtle. Journal of Herpetology. 37:183-185.

Avery, R.A. (1994). Growth in reptiles. Gerontology. 40:193-199.

Balazs, G.H. (1979). Investigations of the growth, food sources and migration of immature Hawaiian Chelonia IUCN Marine Turtle Newsletter. 10:1-3.
Balazs, G.H. (1982). Factors Affecting the Retention of Metal Tags on Sea Turtles Marine Turtle Newsletter. 20:11-14.

Balazs, G.H. (1980). Synopsis of biological data on the green turtle in the Hawaiian Islands. NOAA Technical Memorandum, NMFS, Honolulu, Hawaii, 141 pp.

Balazsa, G.H. and Chaloupka, M. (2004). Thirty-year recovery trend in the once depleted Hawaiian green sea turtle stock. Biological Conservation. 117:491-498.

Bellini, C. (1996). Reproduction and Feeding of Marine Turtles in the Fernando de Noronha Archipelago, Brazil. Marine Turtle Newsletter 74:12-13.

Bjorndal, K.A. (1980). Nutrition and grazing behavior of the green turtle Chelonia mydas. Marine Biology. 56:147-154.

Bjorndal, K.A. (1985). Nutritional Ecology of Sea Turtles. Copeia 3:736-751.

Bjorndal, K. (1997). Feeding ecology and nutrition in sea turtles. In: Lutz, P., Musick, J. (Eds.), The Biology of Sea Turtles. CRC Marine Science Series. CRC Press Inc, Boca Raton, pp. 199-231.

Bjorndal, K.A. and Carr, A. (1989). Variation in clutch size and egg size in the green turtle nesting population at Tortuguero, Costa Rica. Herpetology. 45:181-189.

Broderick, A.C., Godley, B.J., and Hays, G.C. (2001). Trophic status drives inter-annual variability in nesting numbers of marine turtles. Proceedings of the Royal Society of London B. 268:1481-1487.

Broderick, A.C., Glen, F., Godley, B.J. and Hays, G.C. (2003). Variation in reproductive output of marine turtles. Journal of Experimental Marine Biology and Ecology. 288: 95-109.

Carr, A. and Goodman, D. (1970). Ecologic implications of size and growth in Chelonia. Copeia.1970:783.

Chaloupka, M. Y., Limpus, C. J., and Miller, J. D. (2004). Green turtle somatic growth dynamics in a spatially disjunct Great Barrier Reef metapopulation. Coral Reefs. 23:325-335.

Chen T.H, and Cheng I.J. (1995) Breeding biology of the green turtle, Chelonia mydas (Reptilia: Cheloniidae) at Wan-an Island, Peng $\mathrm{Hu}$ Archipelago, Taiwan. I. Nesting ecology. Marine Biology. 124:9-15.

Congdon, J.D. and Gibbons, J.W. (1985). Egg components and reproductive characteristics of turtles: relationships to body size. Herpitologica. 41:194-205.

Deraniyagala, P.E.P. (1953). A coloured Atlas of some vertebrates from Ceylon. Tetrapod Reptiles, Colombo Museum, Colombo, Sri Lanka. 2:101.

Ekanayake E.M.L. Rajakaruna, R.S., Kapurusinghe, T., Saman M.M., Samaraweera, P. and Ranawana, K.B. (2010a). Nesting behaviour of the green turtles at Kosgoda rookery, Sri Lanka. Ceylon 
Journal of Science (Biological Science). 39:109120.

Ekanayake, E.M.L. (2003). Nest site fidelity and nesting behaviour of marine turtles in Rekawa turtle Rookery. M.Phil. Thesis, Postgraduate Institute of Science (PGIS), University of Peradeniya, Sri Lanka.

Ekanayake, E.M.L., Kapurusinghe, T., Saman, M.M., Rathnakumara, A.M.D.S., Rajakaruna, R.S., Samaraweera, P. and Ranawana, K.B. (2010b). Re-nesting movements and post-nesting migrations of green turtles tagged in two turtle rookeries in Sri Lanka. Proceedings of the $30^{\text {th }}$ Annual Symposium on Sea Turtle Biology and Conservation, Goa, India.

Foley, A.M., Peck, S.A. and Harman, G.R. (2006). Effects of Sand Characteristics and Inundation on the Hatching Success of Loggerhead Sea Turtle (Caretta caretta) Clutches on Low-Relief Mangrove Islands in Southwest Florida. Chelonian Conservation and Biology 5:32-41.

Frazer, N.B. and Ladner, R.C. (1986). A growth curve for green sea turtles, Chelonia mydas, in the U.S. Virgin Islands, 1913-14. Copeia. 1986: 798-802.

Glen, F., Broderick, A.C., Godley, B.J. and Hays, G.C. (2005). Pattern in emergence of Green (Chelonia mydas) and Loggerhead (Caretta caretta) turtle hatchlings from their nests. Marine Biology. 146:1039-1049

Goshem L.R., Avens, L., Scharf, F.S., Southwood, A.L. (2010). Estimation of age at maturation and growth of Atlantic green turtles (Chelonia mydas) using skeletochronology. Marine Biology. 157:1725-1740.

Hays, G.C. and Speakman, J.R. (1991). Reproductive Investment and Optimum Clutch Size of Loggerhead Sea Turtles (Caretta caretta) Journal of Animal Ecology. 60:455-462.

Hays, G.C., Adams, C.R. and Speakman, J.R., (1993). Reproductive investment by green turtles nesting on Ascension Island. Canadian Journal of Zoology. 7:1098 - 1103.

Hewapathiranage, S., Jayarathne, S. and Rajakaruna, R.S. (2015). Factors affecting the nest success and sex ratio of hatchery relocated green turtle eggs. iPURSE Peradeniya, Sri Lanka.

Hewavisenthi, S. and S. W. Kotagama (1991). The embryo mortality of the green turtle (Chelonia mydas) in relation to handling of eggs. Proceedings of the Sri Lanka Association for the Advancement of Science. 47:89.

Hirth, H.F. (1980).Some aspects of the nesting behaviour and reproductive biology of marine turtles. American Zoologist. 20:507-523.

Hirth, H.F. (1997). Synopsis of biological data on the green turtle Chelonia mydas (Linnaeus 1758). U.S. Fish and Wildlife Service. Biological Report. 97:1-120.
Iverson, J.B. (1992). Correlates of reproductive output in turtles (Order Testudines). Herpetology Monographs 6:25 -42.

Johnson, S.A. and Ehrhart, L.M. (1996). Reproductive ecology of the Florida green turtle: clutch frequency. Journal of Herpetology. 30:407-410.

Limpus, C.J., Couper, P.J. and Read, M.A. (1994). The green turtle, Chelonia mydas, in Queensland: population structure in a warm temperate feeding area. Memoirs of the Queensland Museum. 35:139-154.

Limpus, C.J. and Chaloupka, M., (1997). Nonparametric regression modeling of green sea turtle growth rates (Southern Great Barrier Reef). Marine Ecology Progress Series. 149:23-34.

Limpus, C.J. and Nicholas, N. (1987). The southern oscillation regulates the annual numbers of green turtles (Chelonia mydas) breeding around northern Australia. Australian Journal of Wildlife Research. 15:157 - 161.

Marcovaldi, M.A., and Laurent, A. (1996). A six season study of marine turtle nesting at Praia do Forte, Bahia, Brazil, with implications for conservation and management. Chelonian Conservation and Biology. 2:55-59.

Marcovaldi, M.A., Godfrey, M.H. and Mrosovsky, N. (1997). Estimating sex ratios of loggerhead turtles in Brazil from pivotal incubation durations. Canadian Journal of Zoology. 75: 755-770.

Miller, J.D. (1997). Reproduction in Marine turtles. In: P.L. Lutz and J.A. Musick (Eds) The Biology of Marine Turtles. CRC Press, Washington DC, 5181.

Miller, J.D. (1999). Determining clutch size and hatching success. In: Eckert, K.L., Bjorndal, K.A., Abreu-Grobois, F.A., Donnelly, M. (Eds.), Research and Management Techniques for the Conservation of Sea Turtles. IUCN/SSC Marine Turtle Specialist Group, Washington, DC, pp. 124129.

Moll, E.O. (1979). Reproductive cycles and adaptations. Pp. 305-331. In M. Harless and $\mathrm{H}$. Morlock (Eds.), Turtles: Perspectives and Research. Wiley and Sons, New York.

Mortimer, J.A. (1990). The influence of beach sand characteristics on the nesting behaviour and clutch survival of green turtles (Chelonia mydas) Copeia. 1990:802-917.

Mrosovsky, N. (1982). Sex ratio bias in hatchling sea turtles from artificially incubated eggs. Biological Conservation. 23:309-314.

Mrosovsky, N., Baptistotte, C, and Godfrey, M.H. (1999). Validation of incubation duration as an index of the sex ratio of hatchling sea turtles Canadian Journal of Zoology 77: 831-835.

Olsson, M. and Shine, R. (1996). Does reproductive success increase with age or with size in species with indeterminate growth? Oecologia. 105:175 178 . 
Özdemir, B. and Türkozan, O. (2006). Hatching Success of Original and Hatchery Nests of the Green Turtle, Chelonia mydas, in Northern Cyprus. Turkish Journal of Zoology. 30:377-381.

Rajakaruna, R.S. and Ekanayake, E.M.L. (2014). Effect of nest depth and nest temperature on the hatching success of green turtle eggs relocated in turtle hatcheries in southwest coast of Sri Lanka. $33^{\text {rd }}$ Annual Symposium on Sea turtle Conservation and Biology. New Orleans, USA

Shine, R. (1992). Relative clutch mass and body shape in lizards and snakes: is reproductive investment constrained or optimized? Evolution 46:828 - 833.

SWOT Scientific Advisory Board (2011). The State of the World's Sea Turtles (SWOT) Minimum Data Standards for Nesting Beach Monitoring, version 1.0. Handbook, 28 pp.

Tiwari, M. and Bjorndal, K.A. (2000). Variation in morphology and reproduction in the loggerheads, Carettacaretta, nesting in the United States, Brazil and Greece. Herpetologica. 56:343-356.

Van De Merwe, J.P., Ibrahim, K. and Whittier, J.M. (2005). Effects of hatchery shading and nest depth on the development and quality of Chelonia mydas hatchlings: implications for hatchery management in Peninsular Malaysia. Australian Journal of Zoology. 53:205-211.
Van Buskirk, J. and Crowder, L.B. (1994). Lifehistory variation in marine turtles. Copeia. 1994: 66-81.

William, H.N., Gutzke, G.C. and Packard, C (1985). Hatching success in relation to egg size in painted turtles (Chrysemys picta) Canadian Journal of Zoology. 63:67-70.

Wood, J. R. and Wood, F.E. (1980). Reproductive biology of captive green sea turtles Chelonia mydas. American Zoologist. 20:499-505.

Zug, G. R. and Balazs, G.H. (1985). Skeletochronological age estimates for Hawaiian green turtles. Marine Turtle Newsletter. 33:9-10.

Zug, G. R., Balazs, G. H., Wetherall, J. A., Parker, D. M. and Murakawa, S. K. (2002). Age and growth of Hawaiian green seaturtles (Chelonia mydas): an analysis based on skeleton-chronology. Fisheries Bulletin. 100: 117-127. 